\title{
VARIABILITY OF SELECTED PHYSICOCHEMICAL CHARACTERISTICS OF DEFROSTED WHITELEG SHRIMPS (LITOPENAEUS VANNAMEI) AFTER CULINARY PROCESSING
}

\author{
Đ. ĐorĐEVIĆa* and H. BuchtovÁ ${ }^{b}$ \\ ${ }^{a}$ Department of Meat Hygiene and Ecology, Faculty of Veterinary Hygiene and Ecology, \\ ${ }^{\text {b}}$ University of Veterinary and Pharmaceutical Sciences, Palackého tř. 1946/1, 61242 Brno. Czech Republic
}

(Received: 11 February 2016; accepted: 29 April 2016)

\begin{abstract}
The aim of the study was to estimate how selected physical and chemical characteristics of defrosted modified atmosphere packaged (MAP) not deveined shrimp (green shrimp with head) (Litopenaeus vannamei) meat are affected by two of the most often used culinary processing (cooking and frying). The experiment was carried out with 61 green shrimps with head (the country of origin: Ecuador; $\mathrm{MAP} 30 \% \mathrm{CO}_{2} / 70 \% \mathrm{~N}_{2}$; stored 8 days at $0{ }^{\circ} \mathrm{C}$ to $+2{ }^{\circ} \mathrm{C}$ ) samples and evaluation of weight loss, $\mathrm{pH}$, total volatile basic nitrogen (TVBN), and trimethylamine (TMA) contents. Weight losses and $\mathrm{pH}$ of examined shrimp samples after cooking and frying were significantly $(\mathrm{P}<0.05)$ lower, while same fluctuations in TVBN and TMA contents were noticed between culinary treatments (cooking, frying) as between different parts of shrimp tails. Significant correlations $(\mathrm{P}<0.05)$ were found between $\mathrm{pH}$ values and freshness indicators (TVBN, TMA-N), emphasizing different ongoing post-mortem metabolic and degradation processes in different parts of edible shrimp (Litopenaeus vannamei) parts (peeled tail).
\end{abstract}

Keywords: weight losses, cooking, frying, $\mathrm{pH}$, freshness indicators

Shrimps have been continuously getting more popular among consumers due to their sensory and nutritional values (high protein content and low fat content), making them economically important worldwide (JAFFRES et al., 2011; BonO et al., 2012).

Shrimp texture and physicochemical properties can be compromised by heat treatment, which is usually applied in culinary preparation (e.g. cooking and frying). Among consumers, frying is the most appreciated culinary method due to the achievement of highly palatable final product, though it cannot be recommended because of the higher fat content in finished product. Weight loss is another adverse influence of heat treatment on shrimp quality, which also causes significant economic losses. The reasons for weight losses are connected with protein disability to hold water and collagen shrinkage, as results of higher temperature exposition (ERdogdu et al., 2004; CARNeiro et al., 2013; Farag, 2013; NASERI et al., 2013).

As for all seafood products, for shrimp also there is a chance for higher concentration of total volatile nitrogen bases (TVBN), and that is why shrimps are usually frozen immediately after capturing or harvesting (Bono et al., 2016). Shrimps are well accepted among consumers, mainly due to their high protein and polyunsaturated fatty acids contents. In many continental countries, such as the Czech Republic, shrimps are usually bought as frozen or defrosted products due to distance from shrimp farming/capturing areas. Since shrimps represent seafood with high active water content, neutral $\mathrm{pH}$, present autolytic enzymes and larger amount of non-protein nitrogen compounds, they can easily undergo decay processes (MAnsouri-Najand, 2012; Zhang et al., 2015). The most often used methods for proteins

\footnotetext{
* To whom correspondence should be addressed.

E-mail: dani_dordevic@yahoo.com
} 
decay estimation in seafood are measurement of TVBN and trimethylamine (TMA) contents (RAEISI et al., 2016). These parameters can be significantly affected by culinary preparation, such as frying, grilling, roasting, microwave, other processing types, and also by storage type (Shiriskar et al., 2010; FARAG, 2013).

Literature overview indicates that in the Czech Republic there have been no studies investigating physicochemical characteristics of retail bought defrosted shrimp. Due to this literature lack, the aim of the study was to monitor how selected physical/chemical characteristics of defrosted MAP packaged green shrimp (Litopenaeus vannamei) meat are influenced by cooking and frying.

\section{Materials and methods}

The samples $(\mathrm{n}=61)$ of retail bought (retail seller: Makro Cash \& Carry, Brno, Czech Republic, importer: 31 Allées des Architectes, Saint-Laurent-du-Var, France), whole nondeveined shrimps (green shrimp with head) (Litopenaeus vannamei), defrosted and packaged in modified atmosphere (MAP 30\% $\mathrm{CO}_{2} / 70 \% \mathrm{~N}_{2}$ ) were used for shrimp experiment. MAP was measured by Check Point II gas analyser (PBI Dansensor AS, Ringsled, Denmark). The country of shrimp origin was Ecuador (farmed). The samples were analysed after 8 days of storage, in the middle of the expiration period stated by the producer on the labelling as 15 days after packaging ( 13 days of shelf life for not opened MAP packaging +2 days of shelf life after opening, storage temperature at $0^{\circ} \mathrm{C}$ to $+2{ }^{\circ} \mathrm{C}$ ). Non-deveined whole bodies and tails (green shrimp with head) were weighted separately before cooking and frying. Cooking was done in water bath (GFL 1012, Turnov, BDL s.r.o., Czech Republic), $10 \mathrm{~min}$ at $90{ }^{\circ} \mathrm{C}$, while frying, in pan, on sunflower oil Lukana (Usti Oils s.r.o., Ústí nad Labem, Czech Republic) lasted $4 \mathrm{~min}$. Weight losses (accurate to $0.00 \mathrm{~g}$ ) were measured by weighing on the equipment Pionneer ${ }^{\mathrm{TH}}$ (Ohaus corp., China). $\mathrm{pH}$ values were measured using InoLab $\mathrm{pH} 730$ digital pHmetre with needle electrode, WTW GmbH, Germany.

Total volatile basic nitrogen content (TVBN) and trimethylamine (TMA-N) content were analysed in raw, defrosted, cooked and fried samples of shrimp tails and bodies. TVBN was determined by direct distillation of the sample deproteinized by trichloroacetic acid according to the regulation EC 2074/2005 (Section II, Chapter I, point 3), proceeded as written in the method of MALLE and TAO (1987), followed by titration on Kjeltec 2300 (FOSS Analytical AB, Höganäs, Sweden). TMA-N was analysed using the same method as for TVBN determination after formaldehyde addition to the samples to block the release of primary and secondary amines.

Statistical significance $(\mathrm{P}<0.05)$ was estimated by $t$-test and ANOVA analysis of variance, with post hoc Tukey's test for finding differences between independent variances. Correlation between shrimp $\mathrm{pH}$ and freshness parameters was conducted by Pearson's correlation analysis. SPSS 20 statistical software (IBM Corporation, Armonk, USA) was used.

\section{Results and discussion}

Weight losses and $\mathrm{pH}$ changes after shrimp cooking and frying are shown in Figures 1 and 2. MAP packaging contained carbon dioxide $\left(\mathrm{CO}_{2}\right): 30.85 \pm 0.86 \%$, oxygen $\left(\mathrm{O}_{2}\right): 0.25 \pm 0.04 \%$, and the rest $(>65 \%)$ was nitrogen $\left(\mathrm{N}_{2}\right)$. 
Comparing cooking and frying before and after deveining, weight changes (weight losses) were significant $(\mathrm{P}<0.05)$ (before deveining - cooking: 16.45 $\pm 3.29 \%$; frying: $42.31 \pm 15.48 \%$, after deveining - cooking: $50.51 \pm 3.25 \%$; frying: $51.65 \pm 18.65 \%$ ). Weight losses between cooking and frying before deveining were also statistically significant. CARNeIRo and co-workers (2013) found $38.5 \pm 0.9 \%$ weight losses in their shrimp samples after cooking, which is lower than our results. Although, weight losses in our shrimp samples after cooking but before deveining are almost similar to the results of ERDOGDU and coworkers (2004), who found weight losses around $17 \%$ for shrimps size $35-44$ numbers $\mathrm{kg}^{-1}$. Authors noted that released tissue water easier reaches surface after protein coagulation in smaller shrimps, and that is the reason for the higher weight loss in them. Male shrimps are bigger than females, so gender influences weight loss during shrimp processing. Smaller weight loss after shrimp frying can be explained by substitution of lost moisture with frying oil, though higher temperature is achieved during frying, which allows moisture content to decrease more readily (NASERI et al., 2013). Higher temperature during frying also affects increment of $\mathrm{pH}$ due to more hydrogen bond breakage and electrostatic interaction (DHANAPALL et al., 2012). Posterior parts of shrimp tails had significantly $(\mathrm{P}<0.05)$ higher $\mathrm{pH}$ in heat untreated and heat treated samples (cooking, frying) in comparison to results obtained for anterior and ventral belly parts of shrimp samples. Glycogen and lactic acid in shrimps decreased rapidly after 6 days of storage (on ice and frozen) and by the $\mathrm{pH}$ values shrimps can be sorted into three groups (prime quality: <7.7; acceptable quality: 7.7-7.95; spoiled shrimp: > 7.95) (DesRosier \& TRESSLER, 1977). All shrimp samples before processing had pH lower than 7.7. After application of cooking and frying, $\mathrm{pH}$ increments are noticeable $(\mathrm{P}<0.05)$ (myofibrils heating is usually associated with $\mathrm{pH}$ increment) (Dhanapall et al., 2012), and the highest values were found in fried posterior parts of shrimp samples (8.36 \pm 0.22$)$, although $\mathrm{pH}$ of all analysed samples were within estimated possible $\mathrm{pH}$ peaks for Litopenaeus vannamei (6.0-8.4) (YeH et al., 1978).

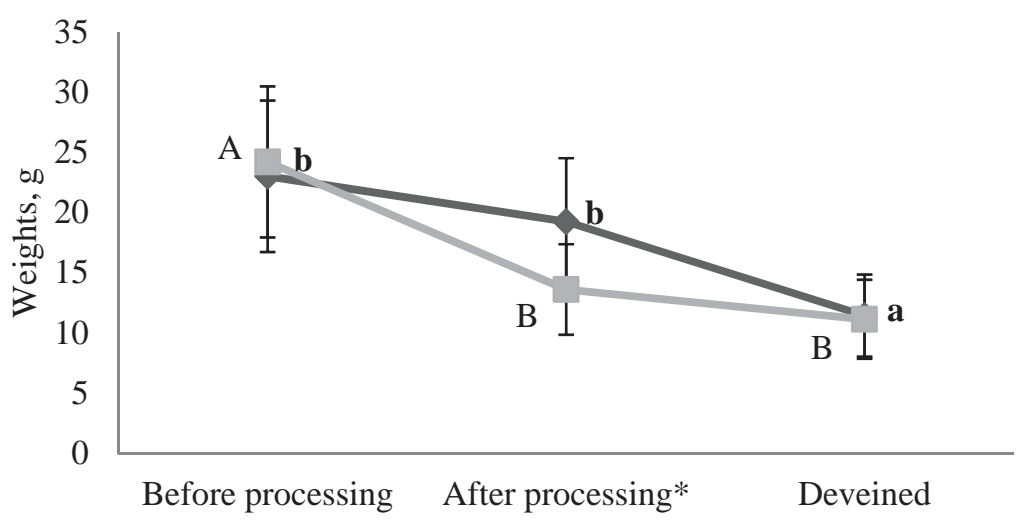

Fig. 1. Shrimp samples' weights before processing, after processing (cooking, frying), and after deveining Parameters values a, b, c / $A, B, C$ are indicators for statistical significance at $\mathrm{P}<0.05$ between weights before processing, after processing, and deveined shrimp samples *t-test $\mathrm{P}<0.05$, between cooking and frying weight losses $>$ : Cooking; $\square$ : Frying 


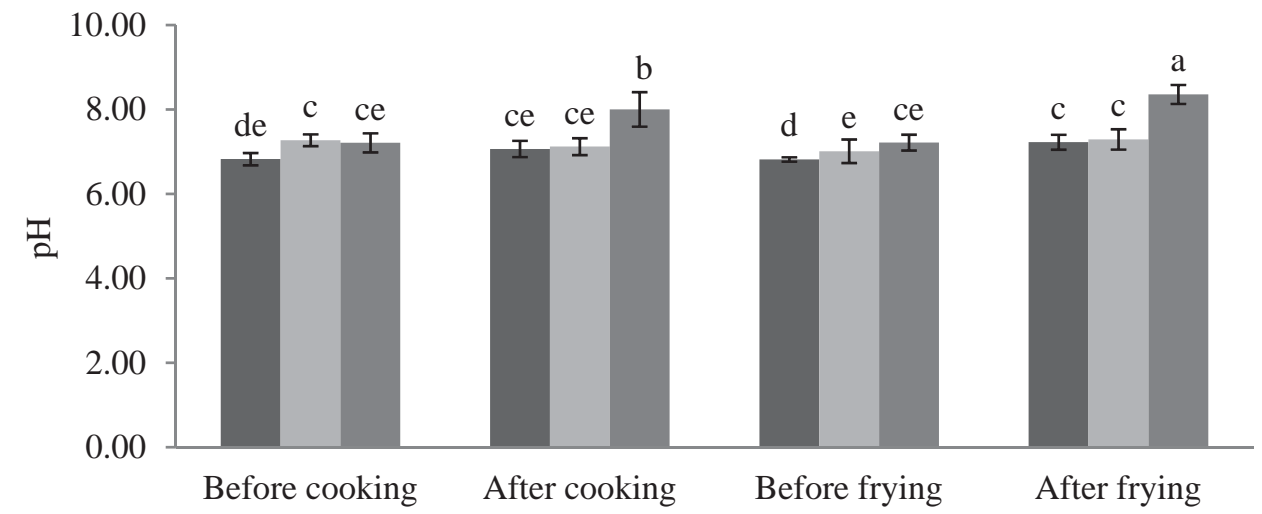

Fig. 2. The changes of $\mathrm{pH}$ in shrimp (Litopenaeus vannamei) tails (anterior, ventral belly, and posterior part) after cooking and frying. $\square$ : Anterior; $\square$ : Ventral belly; $\square$ : Posterior. Parameters values a, b, c, d, e are indicators for statistical significance at $\mathrm{P}<0.05$ between $\mathrm{pH}$ of shrimp after cooking and frying $* t$-test $\mathrm{P}<0.05$ between $\mathrm{pH}$ before and after applied processing (cooking, frying)

TVBN and TMA contents are shown in Figures 3 and 4. TVBN content was statistically significantly $(\mathrm{P}<0.05)$ the highest in raw posterior parts of shrimp tails $(55.6 \pm 5.5 \mathrm{mg} / 100 \mathrm{~g})$, while in other examined samples the values were approximately at the same level (cooked posterior: $44.0 \pm 4.1 \mathrm{mg} / 100 \mathrm{~g}$; fried posterior: $45.6 \pm 3.2 \mathrm{mg} / 100 \mathrm{~g}$; raw anterior: $44.6 \pm 0.4$ $\mathrm{mg} / 100 \mathrm{~g}$; cooked anterior: $44.6 \pm 4.1 \mathrm{mg} / 100 \mathrm{~g}$; fried anterior: $44.8 \pm 1.3 \mathrm{mg} / 100 \mathrm{~g}$; raw mix: $45.6 \pm 6.2 \mathrm{mg} / 100 \mathrm{~g}$; cooked mix: $44.32 \pm 3.1 \mathrm{mg} / 100 \mathrm{~g}$; fried mix: $45.2 \pm 2.3 \mathrm{mg} / 100 \mathrm{~g}$ ). These values are very high, indicating higher degree of shrimp meat decomposition, meaning bigger amounts of ammonia present. Though for shrimp meat there is no estimated TVBN content limit, for unprocessed fishery products the highest allowed is $35 \mathrm{mg} / 100 \mathrm{~g}(\mathrm{EC}, 2008)$. It is also recommended that the product should be rejected if TVBN is over $20 \mathrm{mg} / 100 \mathrm{~g}$ (RAEISI et al., 2016). Higher levels of TVBN can also be linked to the presence of ammonia producing enzymes in shrimp tails, adenosine deaminase and AMP deaminase being the most abundant ones (YEH et al., 1978). Correlations between pH and TVBN (taking into calculation anterior and posterior parts of shrimp tail separately) was found to be statistically significant $(\mathrm{P}<0.05)$, the coefficient of determinations $\left(\mathrm{R}^{2}\right)$ was 0.678 , meaning that $\mathrm{pH}$ accounted for $67.8 \%$ of variation in TVBN content. Taking into consideration that green shrimp samples in the study were opened after 8 days of storage at $+4{ }^{\circ} \mathrm{C}$, our results are in accordance with results of HUANG and co-workers (2016), in whose study shrimp (Litopenaeus vannamei) samples had unacceptable values of TVBN and TMA-N after 7 days storage at $+4{ }^{\circ} \mathrm{C}$.

ZHANG and co-workers (2015) observed an increase in TVBN and TMA-N contents in shrimp samples (Litopenaeus vannamei) packaged in air and MAP packaging for 180 days at $-18{ }^{\circ} \mathrm{C}$, but TVBN and TMA-N contents in their samples stayed below $30 \mathrm{mg} / 100 \mathrm{~g}$ and 11 $\mathrm{mg} / 100 \mathrm{~g}$, respectively, which describe acceptable shrimp quality (MENDES et al., 2005). Almost the same results were gained by authors GoNCALVES and GINDRI (2009) in samples of sea-bob shrimps (Xiphopenaeus kroyeri). Trimethylamine is usually not formed during frozen storage, but dimethylamine content can double after 50 days of frozen storage, which with formaldehyde (added during TMA-N analysis) forms trimethylamine (CINTRA et al., 1999; BRemmer, 2002). Compared with these two studies, our samples had much higher contents of TVBN and TMA-N. TVBN contents in raw shrimp samples, especially posterior 
parts, were close to TVBN limit of $60 \mathrm{mg} / 100 \mathrm{~g}$, which describes severely damaged shrimps (Mendes et al., 2005). All our samples had TVBN content over $40 \mathrm{mg} / 100 \mathrm{~g}$, which, according to some references, is the value of not suitable for human consumption (GoNCALVES \& GINDRI, 2009). The limit of $30 \mathrm{mg} / 100 \mathrm{~g}$ (TVBN) was also reached in ozone treated and ozone untreated shrimp samples (Litopenaeus vannamei) after 10 days of storage on ice $\left(+4^{\circ} \mathrm{C}\right)$, but TMA-N values were below $11 \mathrm{mg} / 100 \mathrm{~g}$ in both types of samples (OKPALA, 2015). Shrimps' high spoilage predisposition was clearly shown in the study of QIAN and co-workers (2015), where shrimp (Litopenaeus vannamei) samples stored at $+4{ }^{\circ} \mathrm{C}$ in modified atmosphere $\left(\mathrm{CO}_{2}\right.$ : $80 \% ; \mathrm{O}_{2}: 10 \% ; \mathrm{N}_{2}: 10 \%$ ), treated with preservative formulation (quercetin, cinnamic acid, 4-hexylresorcinol) also reached $20 \mathrm{mg} / 100 \mathrm{~g}$ TVBN after 12 days of storage. Mendes and co-workers (2005) found that 6 days of storage at temperatures higher than $5^{\circ} \mathrm{C}$ were enough for the formation of excessive TVBN and TMA-N contents in thawed shrimps contaminated with different levels of total bacterial counts and Enterobacteriaceae. The previous study also showed that TVBN content of shrimps packaged in different MAPs can increase significantly, reaching easily $30 \mathrm{mg} / 100 \mathrm{~g}$ even after 2 months of frozen storage. Shrimp shelf-life, same as shelf-life of other seafood, is highly influenced by the time that passed from capturing to putting seafood on ice or freezing it (Bono et al., 2016). JAFFRES and coworkers (2011) were monitoring TVBN content in defrosted shrimp (Panaeus vannamei) tails packaged in MAP, and they did not measure significant fluctuation in TVBN contents (they stayed under $20 \mathrm{mg} / 100 \mathrm{~g}$ ) in control samples not inoculated with spoilage bacteria species.

Trimethylamine (TMA-N) content in anterior, posterior, and in mixed samples of shrimp tails varied, though not significantly $(\mathrm{P}<0.05)$. Higher $\mathrm{pH}$ can be the result of higher concentrations of basic nitrogen substances (e.g. ammonia, amines, peptides, free aminoacids), but higher $\mathrm{pH}$ can also be related to seafood species (Ruiz-Capillas \& Moral, 2001). Correlations between $\mathrm{pH}$ and TMA-N (anterior and posterior parts of shrimp tails included in calculation separately) were statistically significant $(\mathrm{P}<0.05), \mathrm{R}^{2}=0.841$, therefore $\mathrm{pH}$ accounted for $84.1 \%$ of variation in TMA-N content. TMA-N in posterior and anterior parts of shrimp tails after cooking and frying did not differ significantly, but were higher in anterior and posterior parts after frying in comparison to cooked ones. All measured TMA-N contents were well above acceptable limit (MeNDES et al., 2005).

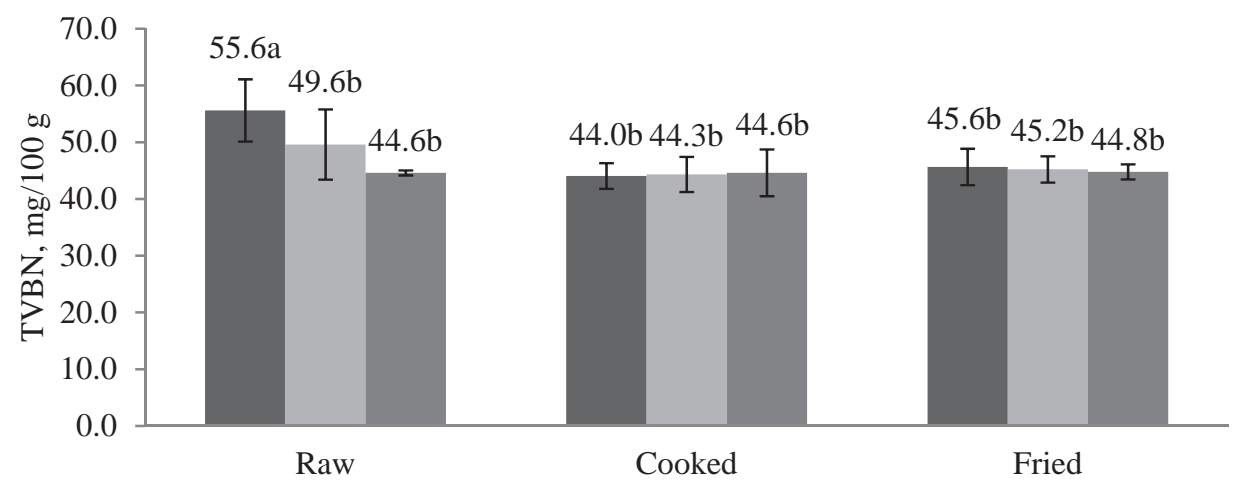

Fig. 3. Total volatile basic nitrogen (TVBN) content in raw, cooked, and fried shrimp samples Parameters values a, $\mathrm{b}$ are indicators for statistical significance at $\mathrm{P}<0.05$ between TVBN content in raw, cooked, and fried shrimps tails and bodies. $\square$ : Posterior; $\square$ : Mix; $\square$ : Anterior 


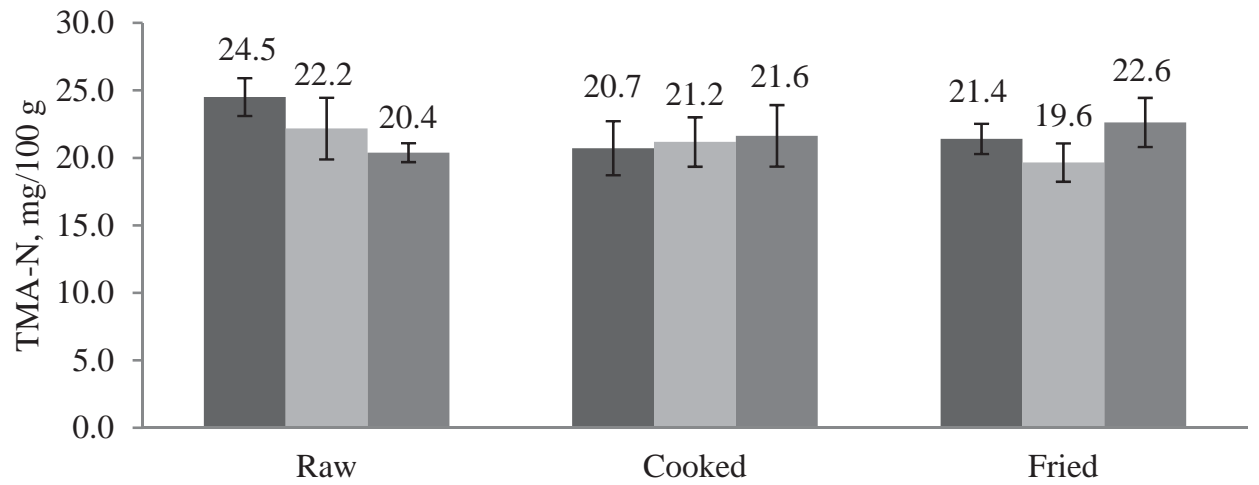

Fig. 4. Trimethylamine (TMA-N) contents in different parts of shrimp tails after cooking and frying. $\square$ : Posterior; $\square$ : Mix; $\square$ : Anterior

\section{Conclusions}

The study emphasized how processing type (cooking, frying) can significantly influence shrimp weight loss, chemical and freshness indicators. Good correlations between $\mathrm{pH}$ and shrimp freshness indicators (TVBN, TMA-N) point out that shrimp freshness is influenced by glycogen/lactic acid metabolism, and that processes occurring in edible shrimp part (shrimp tail) can vary considerably at different points (anterior, posterior) of shrimp tails. High TVBN and TMA-N values in shrimp samples, measured after 8 days of storage at $+4{ }^{\circ} \mathrm{C}$ in MAP, are indicating that producers' estimation of 13 days shrimp shelf-life is exaggerated and probably should be recalculated according to research data. These results are also suggesting that more attention should be paid to storage conditions in retail shops and provision of immediate freezing (after harvesting/capturing) of shrimp intended for this kind of final product (defrosted green shrimps with head, stored at $+2 \pm 2{ }^{\circ} \mathrm{C}$ ).

\section{References}

Bono, G., Gai, F., Peiretti, P.G., Badalucco, C., Brugiapaglia, A., Siragusa, G. \& Palmegiano, G.B. (2012): Chemical and nutritional characterisation of the Central Mediterranean giant red shrimp (Aristaeomorpha foliacea): Influence of trophic and geographical factors on flesh quality. Food Chem., 130, 104-110.

Bono, G., Okpala, C.O.R., Alberio, G.R.A., Messina, C.M., Santulli, A., Giacalone, G. \& Spagna, G. (2016): Toward shrimp consumption without chemicals: Combined effects of freezing and modified atmosphere packaging (MAP) on some quality characteristics of giant red shrimp (Aristaeomorpha foliacea) during storage. Food Chem., 197, 581-588.

Bremmer, H.A. (2002): Safety and quality issues in fish processing. Woodhead Publishing in Food Science and Technology. CRC Press, Boca Raton, FLA. 507 pages.

Carneiro, C.S., Marsico, E.T., Ribeiro, R.O.R., Carlos, A.C.J., Thiago, S.A. \& Edgar, F.O.J. (2013): Quality attributes in shrimp treated with polyphosphate after thawing and cooking: a study using physicochemical analytical methods and low-field ${ }^{1}$ H NMR. J. Food Process Eng., 36, 492-499.

Cintra, I.H.A., Ogawa, N.B.P., Souza, M.R., Diniz, F.M. \& Ogawa, M. (1999): Decomposition of trimethylamine oxide related to the use of sulfites in shrimp. Food Sci. Technol. (Campinas), 19, 314-317.

Desrosier, N.W. \& Tressler, D.K. (1977): Fundamentals of food freezing. AVI Pub. Co., Westport, Conn. (Chapter 8), pp. 318-356. 
Dhanapall, K., Reddy, V.S., Naik, B.B., Venkateswarlu, G., Reddy, A.D. \& Basu, S. (2012): Effect of cooking on physical, biochemical, bacteriological characteristics and fatty acid profile of Tilapia (Oreochromis mossambicus) fish steaks. Arch. Appl. Sci. Res., 4, 1142-1149.

EC (2005): Commission Regulation (EC) No 2074/2005 of 5 December 2005, OJ. L. 338, 22.12.2005, p. 27.

EC (2008): Commission Regulation (EC) No 1022/2008 of 17 October 2008 amending Regulation (EC) No 2074/2005 as regards the total volatile basic nitrogen (TVB-N) limits. OJ. L. 277, 18.10.2008, p. 18

Erdogdu, F., Balaban, M.O., Otwell, W.S. \& Garrido, L. (2004): Cook-related yield loss for pacific white (Penaeus vannamei) shrimp previously treated with phosphates: Effects of shrimp size and internal temperature distribution. J. Food Eng., 64, 297-300.

FARAG, M.M.A. (2013): Effect of different cooking methods on nucleic acid nitrogen bases content of fresh sardine fish and its nutritive value. World J. Dairy \& Food Sci., 8, 156-164.

Goncalves, A.A. \& Gindri, C.S.G. (2009): The effect of glaze uptake on storage quality of frozen shrimp. J. Food Eng., 90, 285-290.

Huang, Y.R., Zelaya, M.F.G. \& Shiau, C.Y. (2016): Changes in biochemical compositions and quality of white shrimp (Litopenaeus vannamei) during storage. J. Aquat. Food Prod. T., 25, 34-45.

Jaffres, E., Lalanne, V., Mace, S., Cornet, J., Cardinal, M., Serot, T., Dousset, X. \& Joffraud, J.J. (2011): Sensory characteristics of spoilage and volatile compounds associated with bacteria isolated from cooked and peeled tropical shrimps using SPME-GC-MS analysis. Int. J. Food Microbiol., 147, 195-202.

Malle, P. \& TAO, S.H. (1987): Rapid quantitative determination of trimethylamine using steam distillation. J. Food Protect., 50, 756-760.

Mansouri-NAJAND, L. (2012): The effect of various methods of defrosting on microbial contamination of frozen banana shrimp (Penaeus merguiensis). Asian Pac. J. Trop. Biomed., 2, 1888-1891.

Mendes, R., Goncalves, A., Pestana, J. \& Pestana, C. (2005): Indole production and deepwater pink shrimp (Parapenaeus longirostris) decomposition. Eur. Food Res. Technol., 221, 320-328.

Naseri, M., Abedi, E., Mohammadzadeh, B. \& Afsharnaderi, A. (2013): Effect of frying in different culinary fats on the fatty acid composition of silver carp. Food Sci. Nutr., 1, 292-297.

OKPala, C O.R. (2015): Quality evaluation and shelf life of minimal ozone-treated Pacific white shrimp (Litopenaeus vannamei) stored on ice. J. Verbrauch. Lebensm., 10, 49-57.

Qian, Y.F., XIE, J., Yang, S.P., Huang, S.L., Wu, W.H. \& Li, L. (2015): Inhibitory effect of a quercetin-based soaking formulation and modified atmospheric packaging (MAP) on muscle degradation of Pacific white shrimp (Litopenaeus vannamei). LWT - Food Sci. Technol., 63, 1339-1346.

Raeisi, S., Sharifi-Rad, M., Quek, S.Y., Shabanpour, B. \& Sharifi-Rad, J. (2016): Evaluation of antioxidant and antimicrobial effects of shallot (Allium ascalonicum L.) fruit and ajwain (Trachyspermum ammi (L.) Sprague) seed extracts in semi-fried coated rainbow trout (Oncorhynchus mykiss) fillets for shelf-life extension. LWT - Food Sci. Technol., 65, 112-121.

Ruiz-Capillas, C. \& Moral, A. (2001): Correlation between biochemical and sensory quality indices in hake stored in ice. Food Res. Int., 34, 441-447.

Shiriskar, D.A., Khedkar, G.D. \& Sudhakara, N.S. (2010): Preparation of boiled and dried products from anchovies (Stolephorus sp.) and studies on quality changes during storage. J. Food Process. Pres., 34, 73-86.

Yeh, C.P.S., Nickelson, R. \& FinNe, G. (1978): Ammonia-producing enzymes in white shrimp tails. J. Food Sci., 43, 1400-1401.

Zhang, B., Ma, L.K., Deng, S.G., Xie, C. \& Qiu, X.H. (2015): Shrimp-life of pacific white shrimp (Litopenaeus vannamei) as affected by weakly acidic electrolyzed water ice-glazing and modified atmosphere packaging. Food Control, 51, 114-121. 